\title{
RECENT DISSERTATIONS
}

STINNE HØRUP HANSEN, 2008:

Fortællinger i Naturvidenskaben - en empiribaseret unders $\emptyset$ gelse af videnskabsteaterforestillin-gen Den Magiske

Kugle og dens forankring i gymnasiepraksis.

Center for Science and Mathematics Education, Department of Mathematics and Computer Sciences. University of Southern Denmark.

\section{Abstract}

The Magic Bullet (in Danish: Den Magiske Kugle) is a Science Theatre Play which communicates a research narrative. The present dissertation documents the various effects resulting from the application of the play as a tool to communicate science to students of the Upper Secondary School. The Magic Bullet is a fairy tale about biophysics embedded within the real world of research. The play conveys to the audience state of the art research as it is put to use in the quest of finding a cure for cancer.

The scope of the dissertation is, through empirical studies, to investigate the students' perception and reception of the instance of being told about science - an instance which in this dissertation is labeled narrative reception. The narrative reception analysis reveals three topical determinants for how the play is received: The students' specific interests, which is closely related to their educational prerequisites for receiving and understanding the play, their general expectations of a science theatre play, and finally what they actually think of the performers.

In relation to the play, two different teaching materials were designed, applied and evaluated. The methodological basis of the project is design - based research, and a range of qualitative methods were applied in the collection of empirical data. Five classes from Upper Secondary School have watched The Magic Bullet: Three classes with a scientific profile and one with a social scientific profile comprising a total of 90 students.

Data obtained from the analysis of the teaching materials show that the students feel that the sequences helped them to process the scientific content of the play through collective learning, which in turn resulted in a more thorough understanding of play.

Based on the results of this study it can be concluded that The Magic Bullet is applicable for students in Upper Secondary School for three purposes: First, as a means to boost the interest for science among young people. Second, the play has proved itself as an excellent tool for both students and teachers to create thorough and logical coherence between subjects. Third, the play is capable of repeating the knowledge, and adds on more to the knowledge, already acquired by the students - thereby supporting their self definition as scientifically literate. These characteristics of the play are more pronounced with regard to students that already have some interests in science which proves the play to be widely applicable irrespective of subject preferences.

Language:

Contact:

ISBN:

\section{Danish with an abstract in English \\ Stinne@sdu.dk \\ 9788792321060}

